\title{
Modularity and network integration: Emergent business models in banking
}

\author{
J.M Liebenau, S.M. Elaluf-Calderwood, and C.M.Bonina \\ Department of Management \\ London School of Economics and Political Science, UK \\ e-mail: \{j.m.liebenau, s.m.elaluf-calderwood, c.m.bonina\}@1se.ac.uk
}

\begin{abstract}
This paper introduces the concept of modularity in financial services, discusses how new value chains are created and addresses emerging opportunities for innovative business models in the digital economy. We argue that innovation occurred in the banking sector despite the lagging adoption of new operational practices but due to technology drive for new ways to provide services. Banking innovation is commonly a matter of case facilitation vs. lock-in, in which the systemic effects of balancing delay vs. fast progress requires business model choices. In the banking sector, where there is little power stability among stakeholders, asymmetrical periods of dynamism are triggered by the modernization of the systems [13].

The main argument of this paper is that we can use models of modularity and network integration to improve our understanding of sustainable emerging banking practices. This is fundamental when establishing the potential contribution of this sector to digital economy models.

Keywords: digital economy, modularity, financial services, banking, innovation, sustainability

\section{Introduction}

The banking sector was one of the first adopters of computers for fast processing of back office operations and many repetitive tasks in the sector. Much of the early commercial development was adopted as part of the move to "informate" banking infrastructure [35]. In the following decade, the internet and the development of mobile devices with chips that allowed secure and encrypted transmission of data fit uncomfortably with the mainframe-based processes that banks had pioneered [8]. The changes involved in the adaptation of mobile banking with secure electronic transfers, digital signatures and other emergent services required new procedures based on modularity [33] and integration.
\end{abstract}

The niche markets created by the modular based banking opportunities will not replace conventional banking. However, due to their exclusivity and direct knowledge of their customers and the provision of specialized services on their networks, such as crowdfunding and peer-to-peer banking they can occupy valuable niches and distinguish themselves from mainstream banking service. They are based on an effective way of thinking about online applications to banking, especially for mobile services. The experimental and emerging business models in this realm consolidate changes to a model that predominated banking systems since the 1970s [35].

Early solutions based on a segregation of the physical and digital infrastructure (e.g. point to point connections and ATM transactions) through a layered approach slowed down the process of change to wireless payments and mobile banking [22]. The later creation of software platforms on mobile systems and the potential to access great quantities of structured and unstructured data (so called "big data") dramatically widened opportunities for banking services.

Elsewhere in the financial services sector, the combination of cutting-edge technologies with the potentials of big data has opened a landscape for emerging business opportunities: new equity platforms based on "crowdfunding", tracking tools to help insurance providers with risk assessments, applications to monitor companies, suppliers and clients, and a whole range of new payment methods based on mobile technologies. These game-changing players are known as Fin Tech businesses - and these include early innovators who provide data-related services to established financial players as well as new companies that are entering traditional financial markets.

In this paper, we draw upon modularity theory to understand some of these changes in areas of innovative financial services, such as those described before - that is, new forms of retail banking, payments systems and crowdfunding. We suggest that these are 
niche sectors with the potential to shift trends in the digital economy.

Payments systems offer a good initial illustration for our argument. Traditional banking payment systems were once single and secure processes enabling control and verification of transactions through a proprietary network. Although this is still largely the case, increasingly these services are changing. They are transferred to networks and cloud services where the processing of transactions has benefitted from the emergence of intermediary markets based on digital technologies that allow some commercial functions to be split into modules that can be integrated to create new services. As a consequence, these new services do not necessarily match the mainstream banking value chain.

Internet usage changes the requirements and characteristics of the payment platform. Banks made significant investments in infrastructure in the 1970s and were slow to adapt to change since, despite innovations in the ways services have been distributed [35]. The main pressure comes, however, as banking users have expectations about the delivery of their services over newer platforms. In the case of mobile payment systems the modular approach can be regarded as distinctly superior in that it provides the means by which to adapt to cloud services, utilize advanced private networks, integrate banking with other forms of access to data, and otherwise exploit strategic opportunities afforded by online processes.

New ways to utilize the integration of physical networks, data, and digital services have become apparent through this emergent modularity usage of the network architecture. They were based on components that were not previously considered relevant to banking, including social networking and local distribution networks for payments [29]. This matters to the digital economy because it forms part of the wider shift of commercial activities on the internet toward modularity and addresses practices and challenges to a leading commercial sector. As the banking environment moves towards a modular architecture for digital services the associated effects are creating new criteria for competition and innovation [30, 34, 31]. In doing so new banking services use novel approaches to the integration of physical networks, data, and digital services. Here we analyze their components and show how they are mashed together to provide attractive services to consumers.

We proceed to describe the concept of modularity, in the digital economy and financial services, followed by an exemplary analysis of its relevance to financial services, whilst highlighting its potential implications for new emergent services. We then describe what the requirements are for these new approaches and their significance for business models.

\section{Modularity}

New interpretations of internet architecture have spurred on a literature on modularity which dates back to Simon [28] and to Langlois and Robertson [15] but is best developed for our purposes by Yoo [32 and 33]. In their defining paper, Langlois and Robertson describe how "innovation in a modular system can lead to horizontal and vertical disintegration, as firms can often best appropriate the rents of innovation by opening them to an outside network of competing and cooperating firms." In this way both products get redefined and the industry that provides it can be reconceptualised. Where technologies reduce the imperatives of scale economies, customers and other niche providers can extensively tailor products to their requirements. Theirs was a development from the work of Teece [23], who offered a framework showing how modularities of value appropriation for innovations take into account the value of interdependent resources. The challenge for us in this literature comes from the fact that these theories and cases come from manufacturing industry and we are applying ideas from production to services, and the special case of services over a digital infrastructure [31].

The application to internet roles is pertinent because of the move from the layered model to roles better described through modularity theory, at least as a descriptor of the most successful new digital enterprise. Here we can show how, for example, network operators became stuck in a layered way of doing business and were unable to anticipate, or strategically to adjust to, digital ways of doing business based on modularity [10 and 19]. In a similar way, legacy banking has been unable or unwilling to adopt modularity, and new digital businesses are finding niches that are revealed by or facilitated by modularity.

In adapting modularity theory to cases in the digital economy we need to make two adjustments. The first is to account for the analogues of manufacturing processes and the second is to accommodate the paradoxes of lock-in that appear when modularity is applied to networked phenomena. These have to some degree been dealt with by Yoo [32], albeit in the form of a critique focusing on the public welfare costs (in terms of innovation and competition) of any favouring of modularity. Let us consider four basic features of modularity, as Yoo [32] does: 
- Near decomposition of a system in modules as a solution to system complexity. Interconnected subsystems can provide ways to describe and operate parts of larger systems, but also conceptualize niches and innovative elements that are interconnected with in some instances weak but non-negligible interactions.

- Interdependencies as a determinant of module boundaries. These are described by Baldwin and Clark [3] as task interdependencies where boundaries are located at "thin crossing points". While this leaves the system open to burdensome recursiveness, in well functioning systems a form of market emerges based on "improvisation, bricolage, and drift" [6].

- Abstractions and hidden information interfaces due to module design. This provides the means for asymmetries that facilitate entrepreneurial innovations of the form necessary to recognize new market niches within sectors.

- The law of requisite variety, or the relationships in a system to external systems. This allows us to conceptualize the relationship between a particular set of functions and the context in which the system operates. That context includes the industry structure, its suppliers and customers, as well as the governance conditions, such as regulatory regimes, within which it operates. The law of requisite variety addresses the variety of responses in relation to the types of disturbances a system experiences and relates the complexity of a system to its context.

Yoo's main point is that modularity is not necessarily efficient or "natural" when aiming to build up new economic models, which is an assumption we can intuitively agree with. This approach to modularity in the emergent banking sector is therefore useful in the following way: by linking structure to systems science literature, it offers a relevant tool to theorize and map a number of cases in the sector. We argue that a modularity approach is helpful to describe what we see, and to understand those players that seize upon it who are best able to find the niches to exploit new ways of doing business. This is because the emergent players have the potential to redefine boundaries and leverage entrenched positions. Some of that leveraging will be in regard to the relationship between highly regulated and less regulated elements of business. Some of it will be in the use of nimble technologies, and some of it will fall into the category of "first mover".

\subsection{The modularity of the digital economy}

Modular product innovation permits relatively rapid learning and refinement of product and part design by either the product owner or multiple partproviders though experimentation $[3 ; 4 ; 15 ; 17$ and 26]. Because a modular product is hierarchically decomposed into multiple loosely coupled parts, each part can be engaged in autonomous innovation contexts and hence change independently $[3 ; 7 ; 15 ; 17 ; 18$ and 26.

Within the digital economy, we can observe certain features of data distribution that, in combination with the layered construction of the internet, consolidate new services through modularity. Figure 1 below offers a good example of this as applied to big data services conceived of through a modular approach [27]. This reconceptualization of the relationships among services through modularity provides us with a means of relating differing types of services and can account for aspects of specialization of purpose, independent rates of change, module substitution, and embedded coordination and assists in the management and mitigation of complexity [16].

Digital Services Landscape : Modularity in data management

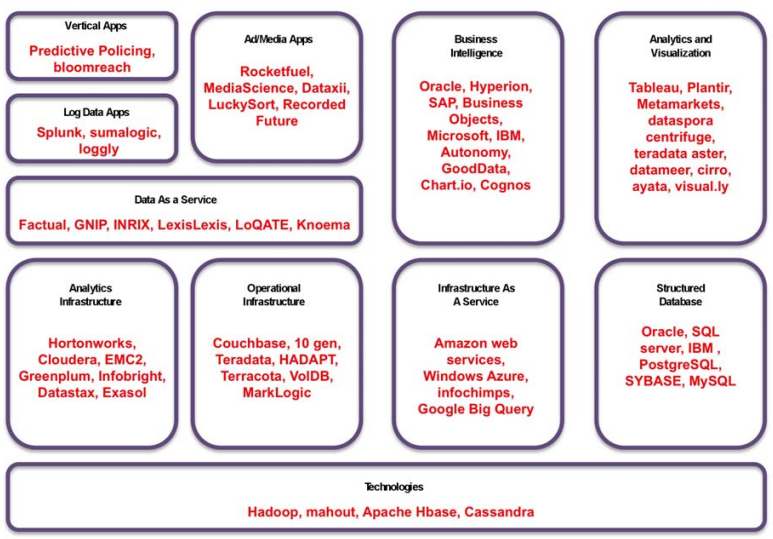

Figure 1. A diagrammatic representation of big data - modularity by service. Source: adapted from Feinleib [9]

Drawing on this conceptualisation, we apply a systemic approach to emerging business models [35] in the financial services sector. We place emphasis on a system-level, layer and modular analysis to explain the type and nature of the business of a series of new emergent companies in the sector. We suggest that in doing so, our approach helps conceptualising not only how value is created, but how it is captured. We show this analysis in section 5, below. Next we consider how to apply this to financial services and the ways we can 
draw on modularity to understand emerging trends in the sector.

\section{Modularity in financial services}

Financial services are being transformed with regard to network, operational and regulatory aspects of the business [25]. Many of the newly enabled digital services in banking combine legacy systems with innovations enabled by emerging and digital economy affordances. Digital technologies have led to hybrid models for banking using mobile phones and social networks [12 and 14], but mainstream banking in advanced industrial economies has been slow in adopting new banking services. The wave of change in part driven from the effects of the 2008 crisis in the financial sectors has brought pressure on the banking sector to meet more requirements to be transparent and in the 'empowerment of consumers'. Some of these innovations use big (and open) data, and this has created new opportunities to develop new business ideas.

In their work on business model innovation, Amit and Zott [35] focus on value creation and value appropriation using a systemic approach. To understand what these two categories mean in the banking sector, we need to clarify what the value propositions are, how these are delivered and the limits to value appropriation. Many companies innovating in the banking industry do so through modular services for the provision of payment systems. This is possible because of the ability of modules to be discrete and to change independently while collectively maintaining compatibility and supporting the overall purpose of the whole entity.

A characteristic of a modularization is neardecomposability [5;17 and 26]. Modules encapsulate their purpose, and relate to one another only through interfaces and not in other direct ways [17; 18, 27]. Thus a module's interference with the inner activities of external modules remains weak [26 and 27]. Further, since interfaces function as proxy module inter-relations, they can be substituted in the abstract architectural description of the whole, for the functions encapsulated by modules [26]. In accordance with Simon [28], the architectural description is higher in abstraction but lower in complexity than the whole that it denotes.

In the case of the internet, and in particular the mobile internet, the adaptability of the modular system facilitates emergent services such as crowdfunding and mobile payment systems. For these services, modularity is not a subset of the previous architecture. It is a distinctive and innovative way to develop further the affordances of digital systems, especially those capable of processing, storing and analyzing big data. For this new sector, modularity is a mash-up of diverse components: social networking, mobile devices, reducing intermediates and increasing social value.

Some of the questions raised by these emerging services are related to the sustainability of drawing resources - for example in the crowdfunding cases - to proceed to build trust with the users. Conventional banking has been slow to understand the interest from their clients to use mobile devices and mobile features when accessing payment services [20]. By doing so they have allowed telecom operators to take the role of being the collectors of data, as the example of m-pesa and other similar services show [11 and 13]. Therefore, it is of great relevance in order to understand what the components not owned by the established banks are and how the use of technology is a means to build trusted business.

To expand on these issues, the next section presents a number of innovations in the financial services and explores ways a modularity approach can help us to make sense of the new emerging services.

\section{Exemplary applications in financial services}

In this section, we illustrate emerging innovation in several areas of financial services. We focus particularly on new businesses (i.e. start-ups), and how they relate, change or support established players and practices in the sector. The cases that we present here come from recent compilations or demonstrations in industry forums, blogs on the top 20 Fin Tech companies in London ${ }^{1}$, the Fin Tech Innovation Labs in London and New York ${ }^{2}$, The Future of Finance conference we attended in 2013, and other specialized activities.

This compilation is exploratory and for this stage we have relied on documentation and informal interviews conducted by key players in the sector. In Table 1 we present our compilation of start-ups and their innovative features in relation to value creation and capture. Our table compiles the companies listed based on the type of "innovative aspects exploited" in the use of the technology and their market niche through a modular structuration of their commercial activities. In order to make these criteria of inclusivity more clear, the table has five columns: the name of the firm, its current business activity description, its modularity characteristics, its market niche (e.g. retail, specialist services, b-2-b, etc.), and target customers.

\footnotetext{
${ }^{1}$ London's top 20 Fin-Tech Start-ups, available at: http://www.doenvision.org/archives/2563

${ }^{2} \mathrm{http} / / / \mathrm{www}$. fintechinnovationlablondon.co.uk/participants.html
} 
We complete our description by contextualizing the firms by establishing a date of entry and historical associations (e.g. some are spin-offs from older financial sector firms, some associated with dot-com type entrepreneurship). Part of our work in progress includes conducting case studies with some of these start-ups to explore these themes in depth.

\begin{tabular}{|c|c|c|c|c|}
\hline & Startup Name & Description of its business core activities & $\begin{array}{l}\text { Innovative aspects } \\
\text { exploited/Market } \\
\text { niche/Modularity }\end{array}$ & $\begin{array}{l}\text { Date of entry and or } \\
\text { historical associations with } \\
\text { the financial sector }\end{array}$ \\
\hline \multirow[t]{5}{*}{ 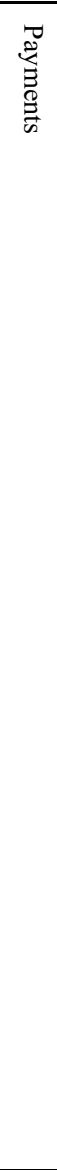 } & $\begin{array}{l}\text { Transfer wise } \\
\text { Payments } \\
\text { (oversees) }\end{array}$ & $\begin{array}{l}\text { This peer-to-peer platform allows people to transfer } \\
\text { money abroad at a lower cost than is traditionally } \\
\text { offered by the banks. The system works by making } \\
\text { sure there are people to want to swap euros for } \\
\text { pounds, at the same time as someone wants to } \\
\text { transfer pounds from the UK }\end{array}$ & $\begin{array}{l}\text { Peer-to-peer platform } \\
\text { Money transfer } \\
\text { protocols } \\
\text { Currency convertors } \\
\text { Decentralized } \\
\text { distribution of money }\end{array}$ & $\begin{array}{l}\text { Created by a Skype former } \\
\text { director }^{3} \text {. } \\
\text { Launched in early } 2011 . \\
\text { Based in London. }\end{array}$ \\
\hline & $\begin{array}{l}\text { The } \\
\text { Currency } \\
\text { Cloud }\end{array}$ & $\begin{array}{l}\text { Aimed to solve the problem of cross-border payments } \\
\text { for small businesses by creating a system that is } \\
\text { transparent and cost effective. It deals in } 140 \\
\text { currencies in } 200 \text { countries. In } 2013 \text { the Currency } \\
\text { Cloud has partnered with Transferwise and secured a } \\
£ 2 \mathrm{~m} \text { round of funding to help it expand globally. }\end{array}$ & $\begin{array}{l}\text { B-2-B services } \\
\text { Payment systems for } \\
\text { SME } \\
\text { Currency convertors } \\
\text { Transparency }\end{array}$ & $\begin{array}{l}\text { Started in } 2009^{4} . \\
\text { Founded by former traders } \\
\text { from the City of London. }\end{array}$ \\
\hline & GoCardless & $\begin{array}{l}\text { Interbank transfers. They're a cheaper and more } \\
\text { convenient way to pay bills but often they are only } \\
\text { available when paying bills from big companies. } \\
\text { GoCardless is a Y Combinator-backed start-up } \\
\text { allowing small merchants to set up interbank transfers } \\
\text { for customers. }\end{array}$ & $\begin{array}{l}\text { Money transfer } \\
\text { protocols } \\
\text { Reduced fees } \\
\text { Decentralized payments }\end{array}$ & $\begin{array}{l}\text { Launched September } 2011^{5} \\
\text { Spinoff from RBS (Royal } \\
\text { Bank of Scotland)/Accel } \\
\text { Partners and Passion Capital } \\
\text { Based in London. }\end{array}$ \\
\hline & MoBank & $\begin{array}{l}\text { MoBank Group creates and operates transactional } \\
\text { systems for mobile commerce, banking and } \\
\text { payments. MoBank is an app which allows you to } \\
\text { manage all of your accounts from your smartphone. } \\
\text { You can check your balance, your transaction history } \\
\text { and set up spending alerts. }\end{array}$ & $\begin{array}{l}\text { Payment systems } \\
\text { Mobile banking } \\
\text { services } \\
\text { Lender for short term } \\
\text { loans } \\
\text { Securing against real } \\
\text { valued goods }\end{array}$ & $\begin{array}{l}\text { Based on mopowered.co.uk } \\
\text { Based in the UK } \\
\text { Founded in } 2012 .\end{array}$ \\
\hline & Ixaris $^{6}$ & $\begin{array}{l}\text { Global payment applications based on open-loop } \\
\text { (Visa and Mastercard) prepaid card schemes. In } 2010 \\
\text { introduced a payment application platform to operate } \\
\text { end-to-end customized payment solutions for } \\
\text { enterprise clients. Authorized by UK Financial } \\
\text { Services Authority Independent Sales Organization } \\
\text { recognized by Visa Member Service Provider of } \\
\text { Mastercard. }\end{array}$ & $\begin{array}{l}\text { Payments systems } \\
\text { B2C, and B-2-B } \\
\text { Sit on top of the } \\
\text { banking system }\end{array}$ & $\begin{array}{l}\text { Headquarters in London; } \\
\text { operations in Malta } \\
\text { Founded in } 2002\end{array}$ \\
\hline 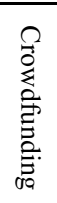 & $\begin{array}{l}\text { Crowdcube } \\
\text { Crowdfunding } \\
\text { (equity) }\end{array}$ & $\begin{array}{l}\text { The platform allows entrepreneurs to pitch for } \\
\text { investment from the public. By getting a group of } \\
\text { smaller investments from Joe Public, start-ups can } \\
\text { by-pass the somewhat painful traditional ways of } \\
\text { raising finance. }\end{array}$ & $\begin{array}{l}\text { Platform } \\
\text { General public } \\
\text { contribution of } \\
\text { investment } \\
\text { Cutting administrative } \\
\text { overheads }\end{array}$ & $\begin{array}{l}\text { Founded in } 2010 . \\
\text { Legacy from Exeter } \\
\text { University Innovation } \\
\text { Center }^{7}\end{array}$ \\
\hline
\end{tabular}

\footnotetext{
${ }^{3}$ http://www.londonlovesbusiness.com/entrepreneurs/start-ups/qa-taavet-hinrikus-co-founder-of-transferwise-which-has-landed-13-millionfunding/2158.article

${ }^{4} \mathrm{http}: / /$ www.thecurrencycloud.com/about-us/

${ }^{5} \mathrm{http}: / / \mathrm{www}$.wired.co.uk/news/archive/2012-05/11/startup-of-the-week-gocardless

${ }^{6} \mathrm{http}: / /$ www.ixaris.com/about-us

${ }^{7} \mathrm{http} / / / \mathrm{www}$. crowdcube.com/pg/crowdcube-inc-about-us-1
} 


\begin{tabular}{|c|c|c|c|c|}
\hline & $\begin{array}{l}\text { Nutmeg } \\
\text { Crowdfunding } \\
\text { (equity) }\end{array}$ & $\begin{array}{l}\text { An online investment manager that makes } \\
\text { investments for you based on your aims and the level } \\
\text { of risk you are willing to take. You can monitor your } \\
\text { investments at any time, withdraw or top up } \\
\text { whenever you like. You can put in as little as } £ 100 \\
\text { per month or } £ 1,000 \text { for the year. }\end{array}$ & $\begin{array}{l}\text { Investment } \\
\text { Associating risk } \\
\text { Monitoring and } \\
\text { transparency }\end{array}$ & $\begin{array}{l}\text { Founded in } 2010^{8} \\
\text { Based in the UK. }\end{array}$ \\
\hline & Crowdbnk & $\begin{array}{l}\text { Crowdsourcing funding, liasion between investors } \\
\text { and people seeking fund, in an open and accountable } \\
\text { manner. The entry point to invest is very low and } \\
\text { uses electronic features to allow investors to monitor } \\
\text { the success they have invested in. }\end{array}$ & Services B2C and B2B & Based in London ${ }^{9}$ \\
\hline \multirow{2}{*}{ 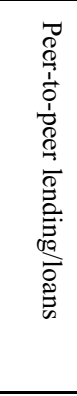 } & $\begin{array}{l}\text { Zopa } \\
\text { Retail banking }\end{array}$ & $\begin{array}{l}\text { Providers of P2P lending, Zopa brings people } \\
\text { together to lend and borrow money. The platform } \\
\text { gives better rates for both lenders and borrowers and } \\
\text { tends to be more efficient than lending from banks. }\end{array}$ & $\begin{array}{l}\text { Peer-to-peer lending } \\
\text { Consumer Loans } \\
\text { Direct liaison between } \\
\text { lenders and borrowers }\end{array}$ & $\begin{array}{l}\text { Founded in } 2005^{10} \\
\text { Based in London. }\end{array}$ \\
\hline & Iwoca & $\begin{array}{l}\text { Instant working capital. Aims to the speedy, online- } \\
\text { retailing bandwagon and offers loans to online } \\
\text { businesses. It assesses the risk of lending based on } \\
\text { quality of customer feedback from online traders (i.e. } \\
\text { Ebay, Amazon), social media presence and credit } \\
\text { history. Typical loan lengths are for three months. }\end{array}$ & $\begin{array}{l}\text { Loans } \\
\text { Focus on online } \\
\text { retailers } \\
\text { Risk assessment for } \\
\text { loans } \\
\text { Shorter time periods } \\
\text { Flexible criteria } \\
\end{array}$ & $\begin{array}{l}\text { Created by a ex vice- } \\
\text { president at Goldman Sachs } \\
\text { banker and ex Deutsche } \\
\text { Bank trader }{ }^{11} \\
\text { Based in London. }\end{array}$ \\
\hline 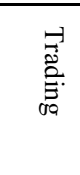 & Finextix & $\begin{array}{l}\text { Fixnetix provides outsourced services for ultra-low } \\
\text { latency trading. In June } 2011 \text { its iX-eCute Field } \\
\text { Programmable Gate Array microchip for ultra-low } \\
\text { latency trading became the world's fastest trading } \\
\text { appliance for the financial markets. }\end{array}$ & $\begin{array}{l}\text { Low latency trading } \\
\text { Specialize market }\end{array}$ & $\begin{array}{l}\text { Founded in } 2006^{12} \text {. } \\
\text { Well established } \\
\text { Based in London. }\end{array}$ \\
\hline 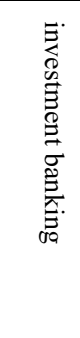 & $\begin{array}{l}\text { Gold-i } \\
\text { Trading }\end{array}$ & $\begin{array}{l}\text { It addresses a gap in the market to enhance the FX } \\
\text { trading process for retail brokers. Gold-i develops } \\
\text { products that give retail brokers the same execution } \\
\text { and risk management tools as institutional brokers at } \\
\text { a fraction of the cost. Its flagship product, Gold-i } \\
\text { Gate Bridge connects brokers trading systems to } \\
\text { global banks. Each transaction through this platform } \\
\text { generates revenue for the start-up which is on course } \\
\text { to turnover } £ 1.5 \mathrm{~m} \text { this year. Its revenues have been } \\
\text { increasing } 100 \% \text { year-on-year since launch. }\end{array}$ & $\begin{array}{l}\text { Specialized services } \\
\text { Traders } \\
\text { Providing playing level } \\
\text { field with electronic } \\
\text { tools } \\
\text { Distributed connectivity } \\
\text { to financial information }\end{array}$ & $\begin{array}{l}\text { UK based (Guildford) but } \\
\text { with offices in Denmark and } \\
\text { Japan. } \\
\text { Spin off from the Surrey } \\
\text { Technology Center }\end{array}$ \\
\hline 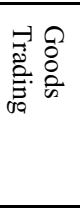 & $\begin{array}{l}\text { Vinetrade } \\
\text { Trading }\end{array}$ & $\begin{array}{l}\text { A wine trading platform which allows the user to buy } \\
\text { and sell fine wines directly with other investors - } \\
\text { cutting out the brokers. Fees are } £ 50 \text { per trade as } \\
\text { opposed to an average of } 10-20 \% \text { charged by } \\
\text { traditional wine brokers. Easy-to-use, transparent } \\
\text { service. }\end{array}$ & $\begin{array}{l}\text { Distributed trading } \\
\text { Cutting out } \\
\text { intermediate layer }\end{array}$ & $\begin{array}{l}\text { Company ran out of } \\
\text { investment. } \\
\text { Was only in operation for } \\
18 \text { months and close down } \\
\text { in Feb } 2013^{13}\end{array}$ \\
\hline 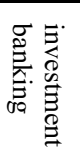 & $\begin{array}{l}\text { Tradable } \\
\text { Trading }\end{array}$ & $\begin{array}{l}\text { Tradable, the world's first open trading platform, } \\
\text { allows traders to create a completely bespoke, online } \\
\text { platform so they can work in a way that best suits } \\
\text { them. }\end{array}$ & $\begin{array}{l}\text { Defined as a platform } \\
\text { Bespoke solutions }\end{array}$ & $\begin{array}{l}\text { Not operational yet }{ }^{14} \text {. } \\
\text { Beta testing }\end{array}$ \\
\hline
\end{tabular}

\footnotetext{
${ }^{8} \mathrm{http}: / /$ www.nutmeg.com/about/the-nutmeg-story

${ }^{9} \mathrm{http} / / / \mathrm{www}$.growthbusiness.co.uk/growing-a-business/business-finance/2144181/crowdbnkand39s-attempt-to-bridge-the-crowdfundingdivide.thtml

${ }^{10} \mathrm{http}$ ///uk.zopa.com/about-zopa/about-zopa-home

${ }^{11} \mathrm{http}: / /$ www.iwoca.co.uk/about_us/

${ }^{12} \mathrm{http}: / /$ www.fixnetix.com/our-company/about-fixnetix/

${ }^{13} \mathrm{http}: / /$ vinetrade.com

${ }^{14} \mathrm{http}: / /$ tradable.com/\#why
} 


\begin{tabular}{|c|c|c|c|c|}
\hline 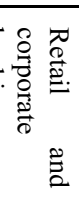 & $\begin{array}{l}\text { The Open Bank } \\
\text { Project }\end{array}$ & $\begin{array}{l}\text { Provides an open source "API for banks" that } \\
\text { developers and companies can use to build } \\
\text { applications and services based on the account } \\
\text { holder's transaction data. It uses a secure enterprise } \\
\text { technology and supports secure Internet protocols } \\
\text { such as OAuth. }\end{array}$ & $\begin{array}{l}\text { The "bank as a } \\
\text { platform" principle } \\
\text { Retail and corporate } \\
\text { banking services }\end{array}$ & $\begin{array}{l}\text { Based in Berlin and London } \\
\text { Founded in } 2010 \\
\text { About to release API with } \\
\text { two major banks as part of } \\
\text { FinTech Lab }\end{array}$ \\
\hline 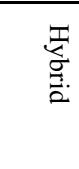 & Duedil & $\begin{array}{l}\text { A free-to-access, database of company information. } \\
\text { Duedil (a play on due diligence) aggregates } \\
\text { information from various sources such as Companies } \\
\text { House and credit ratings. Supporting a whole range of } \\
\text { other activities. }\end{array}$ & $\begin{array}{l}\text { Information } \\
\text { management } \\
\text { Credit ratings } \\
\text { Transparency } \\
\text { B2B }\end{array}$ & $\begin{array}{l}\text { Founded in } 2009 . \\
\text { Created with venture } \\
\text { capitalist money }{ }^{15}\end{array}$ \\
\hline 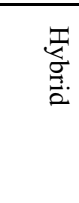 & Gekko & $\begin{array}{l}\text { A dedicated service provider of spread betting and } \\
\text { CFDs. Gekko aims to provide its clients the most } \\
\text { innovative, transparent, cost-efficient and intuitive } \\
\text { execution of financial products in the market place. } \\
\text { The interface - TradeHub is designed to be easy to } \\
\text { use and customizable. }\end{array}$ & $\begin{array}{l}\text { Betting } \\
\text { Bespoke solutions } \\
\text { Customization }\end{array}$ & $\begin{array}{l}\text { Founded in } 2009^{16} \text {. } \\
\text { Founded by a CEO of ABN } \\
\text { AMRO market index } \\
\text { Based in London }\end{array}$ \\
\hline 总 & ChilliMint & $\begin{array}{l}\text { A retail financial services consultancy which aims to } \\
\text { help retail clients transform banking and card } \\
\text { payments. }\end{array}$ & $\begin{array}{l}\text { Retail SMEs } \\
\text { Reduce fees from card } \\
\text { payments }\end{array}$ & $\begin{array}{l}\text { Created by a group of } \\
\text { former bankers } \\
\text { (Barclays/Egg). } \\
\text { Founded in } 2011^{17} \\
\text { Based in the UK }\end{array}$ \\
\hline 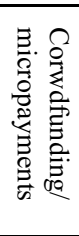 & Flattr & $\begin{array}{l}\text { Flattr has created a platform where content lovers can } \\
\text { give a little to the creators. Users decide how much } \\
\text { they would like to give each month. If they find } \\
\text { something they want to donate to and there is a Flattr } \\
\text { button next to it - they simply press it. At the end of } \\
\text { the month their initial donation is divided-up between } \\
\text { all of the people whose Flattr buttons they pushed. }\end{array}$ & $\begin{array}{l}\text { Platform } \\
\text { Monetization of content } \\
\text { Reaching consumers in } \\
\text { alternative way } \\
\text { Tracking of } \\
\text { contributions }\end{array}$ & $\begin{array}{l}\text { Founded in } 2010^{18} \\
\text { Not clear where is based, } \\
\text { but it is not UK centric. }\end{array}$ \\
\hline 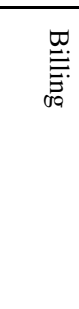 & Market Invoice & $\begin{array}{l}\text { MarketInvoice turns outstanding invoices into cash } \\
\text { for UK-based SMEs. It acts as an auction house for } \\
\text { invoices. It hopes to solve cash flow problems that } \\
\text { many smaller companies face. Institutional investors } \\
\text { bid for the invoices, like eBay for outstanding bills. } \\
\text { Medium-sized companies set up a payment platforms } \\
\text { for their small suppliers to get paid within five days } \\
\text { in return for a discount of between } 3 \% \text { and } 5 \% \text { on } \\
\text { invoice value. }\end{array}$ & $\begin{array}{l}\text { Platform } \\
\text { Retail } \\
\text { B-2-B } \\
\text { Invoicing } \\
\text { Payment } \\
\text { Auction House } \\
\text { SME focus } \\
\text { Small loans and interest } \\
\text { rate }\end{array}$ & $\begin{array}{l}\text { Founded in February } 2011^{19} \text {. } \\
\text { UK based }\end{array}$ \\
\hline
\end{tabular}

Table 1: Case Studies

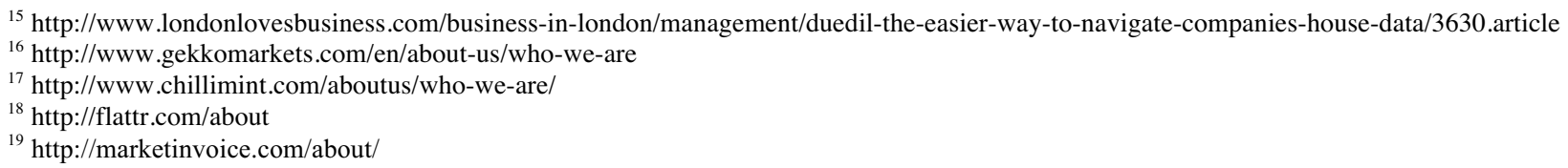


We provide a discussion that identifies groupings, commonalities, trends and other synthesizing features In section 5 we link Figure 1 to Figure 2 and provide further interpretation of the phenomenon. Key example of modularity for the financial services are the use of application protocol interfaces or APIs from developers to integrate different services and create new businesses for consumers. As banks are not in the position to define those APIs, nor other digital standards, they are relegated to roles such as compiling and verifying data and usually do not add functionality to APIs. In this way they have arguably abandoned the field of digital innovation to those who are better able to configure business practices in a modular manner.

The main concern of the creators of these new companies is to provide an alternative to the current banking structure. The services that they provide fall into categories such as access and ranking of risk for credit, the reduction of middle agents and hence some fees for commercial transactions, the creation of social platforms, and evolving established services such as currency convertors.

\section{Discussion}

In this section we contrast this approach to emergence with the legacy and layered model of financial services and emphasize how different the emergent landscape is from the past. We consider which aspects are growing and seem to be lucrative, and what effect that is likely to have on incumbents, either forcing change or threatening their size, prosperity and perhaps even survival. Our analysis drives us to address questions about the novelty, significance and modular character of emerging businesses.

What is different? The legacy financial services sector grew up around the relationships among banks and finance companies plus a large intermediate market of firms offering specialist products and services. Some of these are large consulting companies, some niche providers of goods such as analytical software and services in areas such as security and customer profiling. While these occupants of the intermediary marketplace were a part of the larger system, they did not perform modular roles for the most part in that they largely occupied straightforward supplier positions and were more clearly subsets of simple relationships with customer-facing firms.

The new Fin Tech firms differ in three main ways. One is that they occupy less straightforward positions within the legacy system and are carving out new niches that span products and services in novel ways. Another is that they define their relationship to customers flexibly, sometimes being engaged in mass retail activities, sometimes serving legacy financial sector firms while offering services outside the sector. The third is that they are entering the market using data handing technologies that lower entry barriers and exploit novel information handling approaches. These include in many cases advanced uses of internet functionalities such as online data aggregation, using social network technologies and web access to niche markets. Some of the firms relate specifically to new digital economy businesses by providing them specialist services such as assistance in monetizing web-based commerce, while others regard their target customers as those who expect their services providers to be familiar with business applications of social networking and other web-based applications.

Another novel feature is the way that many Fin Tech firms build flexibility into their business models, allowing for re-combinations of functionalities based on changing user requirements. Some of those engaged in providing finance, for example, use crowdsourcing to accumulate resources and also judge risks, especially for web-based businesses, in ways that are unfamiliar to legacy financing firms. Some engaged in payment systems use virtual currencies in ways that redefine currency exchange and settlement and provide opportunities to non-banking businesses to participate in monetary circulation.

The emergence of these new businesses is significant not only because they bring innovation to the sector generally. They are also exemplars or showcases of new uses of information and communication technologies. While for the most part the niches they occupy are not major threats to the core businesses of financial services firms, they introduce alternatives to well-established ways of doing business. Those that conduct business in regulated sectors also challenge assumptions about how financial services might be governed in the future. For the most part the boundaries between regulated and unregulated practices are not being disputed, so crowdsourced financing is clearly subject to financial services regulations. However, recent responses to virtual currencies such as Bitcoin and the financial advisory functions of some firms will call into question how national and international governance might need to respond.

The modular character of the new digital landscape forms close links between Fin Tech and the use of the open internet as well as the emerging hybrid internet of mobile data, private transport and peering and other architectural forms. As the internet 
is itself transformed with intermediation through relationships defined by APIs the relationship between providers of services and of infrastructure, these emerging firms represent new use cases of ICT. In all these ways, the emergence of these new business models in banking services understood through modularity provides us with a new way to conceptualize the landscape, as seen in Figure 2.

Emerging Banking Sector Landscape

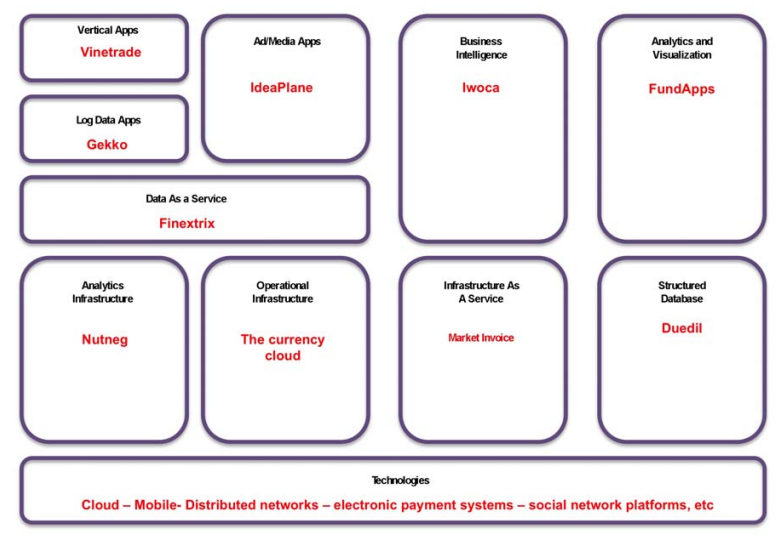

Figure 2: Transposing the big data modularity diagram to the emergent banking sector.

In Figure 2 we have applied the notion of modularity as expressed in the categories of Figure 1 to the Fin Tech businesses. We can see that by transposing these emerging features of the banking sector we are not only re-classifying the business niches they work in but are also demonstrating interrelationship that are potentially highly stable and sustainable. One can distinguish this phenomenon from, for example, the unsustainable dot-com businesses of the late 1990s by their modular characteristics, especially those that ensure greater interrelationships through weak links, the opportunities for rapid innovation, their ability to facilitate flexible organizational characteristics, and low coordination costs.

\section{Conclusion}

As Yoo [31] describes, these features of modularity involve tradeoffs, also. While the coordination costs may be low, the initial set-up costs are high, although they are largely borne by individual risk-taking units and do not seem to be a major expense to the legacy system. They also may forestall certain kinds of innovation, favoring other types. In other modular systems tradeoffs are made between, for example, interconnection standards
(USB ports and radio frequencies) and the opportunities to innovate freely with such mechanisms. Similarly, there are tradeoffs between stable systems and the drift that modularity facilitates as it moves between design and spontaneity.

Our conclusions are both theoretical, in that we show how the theory of modularity can be applied in this way, and they are empirical in that they extend the utility of the theory to explain emerging financial sector activities. The innovative character of these firms is apparent in the wealth of new products and services but also in the new business models that they utilize. Leading financial services firms recognize their innovative character, especially banks but also large established services providers such as Accenture; and it is changing some of their practices.

The sustainability of these businesses and the system that they have formed could yet develop in a number of different ways. One possibility is that they become largely absorbed into a reformed financial services sector, much as emergent biotechnology companies in the 1980s became absorbed by big pharmaceutical firms, either through acquisition or through traditional value chain relationships. Another is that modularity could be seen as an answer to the criticisms of the financial services sector's fragility, dependence and otherwise unsustainable features.

Further research will test the sustainability of these modular forms in financial services and explore the regulatory and policy dimensions of the changing landscape. We will also delve deeper into the functioning of these firms to understand how new ICT is being used and especially how flexible uses of big data and social networking are being exploited. We will also explore the lifecycles of these firms to measure their changing value and to understand what changing relationships they have to legacy firms. In the meantime, we can see that the opportunities to emerge and function within a modular system has generated a flourishing of innovation that challenges, and benefits, many stakeholders in the financial services sector.

\section{Acknowledgements}

The authors wish to thank the RCUK Digital Economy programme on its sub-themes Digital Economy 'New Economics Models' Network (NEMODE+), grant number EP/K003542/1, and Sustainable Society Network + , grant number $\mathrm{EP} / \mathrm{K} 003593 / 1$ for the funding provided to the LSE research team to do research on the themes of this paper. 


\section{References}

[1] Amit, R. and C. Zott (2012), 'Creating Value Through Business Model Innovation', MIT Sloan Management Review, vol. 53, no. 3, pp. 41-49.

[2] Baldwin, C. Y. and K. B. Clark (1997). "Managing in the Age of Modularity." Harvard Business Review 75(5): 84-93.

[3] Baldwin, C. Y. and K. B. Clark (2000). Design Rules, Vol. 1: The Power of Modularity. Cambridge, MA, MIT Press.

[4] Baldwin, C. Y. and J. Woodard (2009). Platforms, Markets, and Innovation. The Architecture of Platforms: A Unified View. in A. Gawer (ed). Cheltenham, UK, Edward Elgar: 19-44.

[5] Baldwin, C. Y. and K. B. Clark (2006). "The architecture of participation: Does code architecture mitigate free riding in the open source development model?" Management Science 52(7): 1116.

[6] Blanchette, J.-F. (2011) "A material history of bits", 62 Journal American Society Information Sciences.1042, 1047 [7] Clark, K. B. (1985). "The Interaction of Design Hierarchies and Market Concepts in Technological Evolution." Research Policy 14(5): 235-251.

[8] Dahlberg, T., N. Mallat, et al. (2006). "Mobile Payments: A Review of Past, Present, and Future Research." ECRA (Electronic Commerce Research and Applications) Journal's Special Issue on Mobile Payments.

[9] Feinleb, D., 2012. The Big Data Landscape. Forbes.com. Available at:

http://www.forbes.com/sites/davefeinleib/2012/06/19/the-

big-data-landscape/ Accessed 25 May 2013.

[10] Garud, R., A. Kumaraswamy, et al., Eds. (2003). Managing in the Modular Age: Architecture, Networks and Organisations. Bodmin, Cornwall, UK, Blackwell.

[11] GSMA (2011). European Mobile Industry Observatory. London, GSMA 74.

[12] GSMA (2013). Mobile Policy Handbook - An insider's guide to the issues. London, UK, GSMA: 48.

[13] Khianarong, T. and J. Liebenau (2009). Banking on Innovation -Modernisation of Payment Systems, Springer.

[14] Kusimba, S., C. Harpieth, et al. (2013). Social Networks of Mobile Money in Kenya. Nairobi, Institute for Money, Technology and Financial Inclusion (IMTFI): 33.

[15] Langlois, R. N. and P. Robertson (1992). "Networks and Innovation in a Modular System: Lessons from the Microcomputer and Stereo Component Industries." Research Policy 21: 297-313.

[16] Langlois, R. N. (2002). "Modularity in Technology and Organization." Journal of Economic Behavior \& Organization 49(1): 19-37.

[17] Langlois, R. and G. Garzarelli (2008). "Of Hackers and Hairdressers: Modularity and the Organizational Economics of Open-source Collaboration." Industry and Innovation 15(2): 125-143.

[18] LaMantia, M. J., Y. Cai, et al. (2008). Software Systems Using Design Structure Matrices and Design Rule Theory: Two Exploratory Cases. Seventh Working IEEE/IFIP Conference on Software Architecture, Vancouver, BC, WICSA 2008.
[19] Liebenau, J., S. M. Elaluf-Calderwood, and P. Karrberg (2012). "A critical analysis of the effects of internet traffic on business models of telecom operators" a white paper of the LSE \& ETNO research collaboration programme.

[20] Maer, L. and N. Broughton (2012). Financial Services: contribution to the UK economy. London, UK, Economic Policy and Statistics - House of Commons Library: 7.

Mayer-Schonberger, V. and K. N. Cukier (2012). Big Data - A Revolution That Will Transform How We Live Work and Think. London, UK, John Murray.

[21] OECD (2013). Exploring Data-Driven Innovation as a New Source of Growth: Mapping the Policy Issues Raised by "Big Data", OECD Digital Economy Papers, No 222, OCED Publishing: 44.

[22] Persoon, M. (2009). Mobile Banking and Payments. Gothenburg, Sweden, Berg Insight: 4.

[23] Teece, D. (1987). Profiting from technological innovation: Implications for integration, collaboration, licensing, and public policy. The Competitive Challenge, [24] Teece. D Cambridge, MA, Ballinger: 285-205.

[25] The Economist, 'The bite is worse than the bark', The Economist, 11-Mar-2013.

http://www.economist.com/news/special-report/21577190new-regulation-poses-threat-investment-banks-and-moreway-bite

[26] Sanchez, R. A. and J. T. Mahoney (1996). "Modularity, flexibility and knowledge management in product and organization design." Strategic Management Journal 17: 63-76.

[27] Schilling, M. A. (2000). "Toward a General Modular System Theory and its Application to Interfirm Product Modularity." Academy of Management Review 25(2): 312334.

[28] Simon, H. A. (1965). The Shape of Automation for Men and Management. New York, Harper \& Row.

[29] Yoo, Y., Henfridsson, O., and Lyytinen, K., 2010. Research Commentary-The New Organizing Logic of Digital Innovation: An Agenda for Information Systems Research. Information Systems Research, 21 (4), 724-735. [30] World Bank (2008). "Banking Services for Everyone? Barriers to Bank Access and Use around the World." The World Bank Economic Review 22(3): 397-430.

[31] Yoo, Y., Boland, R.J., Lyytinen, K., and Majchrzak, A., 2012. Organizing for Innovation in the Digitized World. Organization Science, 23 (5), 1398-1408.

[32] Yoo, C. S. (2012a). Modularity Theory and Internet Policy. TPRC. George Mason University, Arlington, VA: 61.

[33] Yoo, C. S. (2012b). The Dynamic Internet: How Technology, Users and Businesses are Transforming the Network, AEI Press.

[34] Zott, C., Amit, R., and Massa, L., (2011). The Business Model: Recent Developments and Future Research. Journal of Management, 37 (4), 1019-1042.

[35] Zuboff, S. (1988). In the Age of the Smart Machine: The Future of Work and Power. New York, Basic Books 